\title{
Climate Change Impact on Climate Extremes and Adaptation Strategies in the Vea Catchment, Ghana
}

\author{
Isaac Larbi, Clement Nyamekye, Fabien C. C. Hountondji, \\ Gloria C. Okafor, and Peter Rock Ebo Odoom
}

\section{Contents}

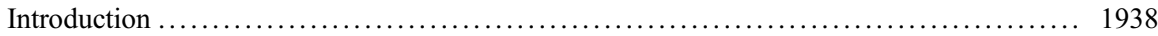

Description of the Study Area and Methodology ................................ 1940

Observation and Climate Change Scenario Datasets .............................. 1941

Climate Extreme Indices Analysis ........................................... 1942

Presentation of Results and Discussion ..................................... 1942

Annual Rainfall and Temperature Projections and Trends ....................... 1942

This chapter was previously published non-open access with exclusive rights reserved by the Publisher. It has been changed retrospectively to open access under a CC BY 4.0 license and the copyright holder is "The Author(s)". For further details, please see the license information at the end of the chapter.

I. Larbi $(\bowtie)$

Climate Change and Water Resources, West African Science Service Centre on Climate Change and Adapted Land Use (WASCAL), Université d'Abomey-Calavi, Cotonou, Benin

School of Sustainable Development, University of Environment and Sustainable Development, Somanya, Ghana

Department of Civil Engineering, Faculty of Engineering, Koforidua Technical University,

Koforidua, Ghana

e-mail: larbi.i@edu.wascal.com

C. Nyamekye

Department of Civil Engineering, Faculty of Engineering, Koforidua Technical University,

Koforidua, Ghana

F. C. C. Hountondji

Faculté d'Agronomie, University of Parakou, Parakou, Benin

G. C. Okafor

Department of Civil Engineering, Nigeria Maritime University, Delta-State, Nigeria

P. R. E. Odoom

Climate Change and Water Resources, West African Science Service Centre on Climate Change and Adapted Land Use (WASCAL), Université d'Abomey-Calavi, Cotonou, Benin 
Trends and Projected Changes in Extreme Rainfall Indices ....................... 1943

Temperature Extreme Indices Projections and Trends ........................... 1944

Climate Change and Climate Extreme Impacts at the Study Region .................. 1946

Existing and Recommended Adaptation Strategies to Address Poverty and Ensure Sustainable

Livelihoods in the Catchment .................................................... 1949

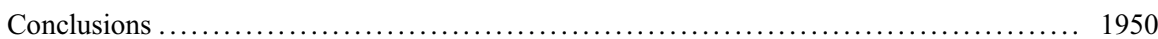

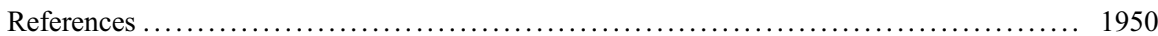

\section{Abstract}

Climate change impact on rainfall and temperature extreme indices in the Vea catchment was analyzed using observation and an ensemble mean of bias-corrected regional climate models datasets for Representative Concentration Pathway (RCP 4.5) scenario. Rainfall extreme indices such as annual total wet-day precipitation (PRCPTOT), extremely wet days (R99P), consecutive wet days (CWD), consecutive dry days (CDD), and temperature indices such as warmest day (TXx) and warmest night (TNx) from the Expert Team on Climate Change Detection Monitoring Indices (ETCCDMI) were computed for both the historical (1986-2016) and future (2020 2049) period using the RClimdex. The parametric ordinary least square (OLS) regression approach was used to detect trends in the time series of climate change and extreme indices. The results show an increase in mean annual temperature at the rate of $0.02{ }^{\circ} \mathrm{C} /$ year and a variability in rainfall at the catchment, under RCP 4.5 scenario. The warmest day and warmest night were projected to increase by $0.8^{\circ} \mathrm{C}$ and $0.3{ }^{\circ} \mathrm{C}$, respectively, in the future relative to the historical period. The intensity (e. g., R99p) and frequency (e.g., CDD) of extreme rainfall indices were projected to increase by $29 \mathrm{~mm}$ and 26 days, respectively, in the future. This is an indication of the vulnerability of the catchment to the risk of climate disasters (e.g., floods and drought). Adaptation strategies such as early warning systems, availability of climate information, and flood control measures are recommended to reduce the vulnerability of the people to the risk of the projected impact of climate extreme in the future.

\section{Keywords}

Climate change $\cdot$ Climate models $\cdot$ Early warning systems $\cdot$ Climate extreme indices $\cdot$ Vea catchment

\section{Introduction}

In the last century, global surface temperature has increased by $0.71{ }^{\circ} \mathrm{C}$ with significant warming observed in many regions (Trenberth et al. 2007). This increase in global surface temperature reveals more warming of land than the oceans and has diverse consequences on water resources and the livelihood of people. In view of this, much attention has been given to climate change and extremes over the past decades (New et al. 2006; Larbi et al. 2018; Adeyeri et al. 2019) due to its intense impact on natural and human systems. At the study region, the high variability in 
rainfall has also resulted in higher frequency of flood and drought events, putting the socioeconomic activities at risk (Awotwi et al. 2015).

The impact of climate change on climate extremes and other sectors require tools for its assessment, and the most common approach for the assessment is the use of climate model outputs. Though Global Circulation Models (GCMs) have been widely used for various climate change studies (Minville et al. 2009; Chen et al. 2012; Panday et al. 2015), it is not suitable for analyzing the projections on a regional or local scale due to its coarse resolution nature (Xu 1999; Maraun et al. 2010; Seager and Vecchi 2010). In West Africa regions, GCMs are unable to represent key features of the West African monsoon (WAM) such as the Africa Easterly Waves (AEWs), Africa Easterly Jets (AEJ), and Tropical Easterly Jets (TEJ) (Sylla et al. 2013). Regional climate models (RCMs) are therefore used in climate change studies because of its ability to accurately take into account orography, thus providing a better reproduction of regional climates (Sylla et al. 2013).

Extreme climatic events such as heat waves, floods, and droughts affect lives and livelihoods of people over varied regions (Alexander et al. 2006). Floods and droughts generate socioeconomic effects such as hunger, habitat, and infrastructure destruction. Over $40 \%$ of the populace has encountered hunger situations, that resulted from failure of one-third of crop produced when compared to 2010 data, leading to humanitarian appeals (Sarr 2012; FAO 2013). These and other ensuing impacts have necessitated the analysis of changes in future climate extremes necessary in reducing potential social, economic, and ecological consequences (Amuzu et al. 2018; Bohle et al. 2018). This need has necessitated studies in the analysis of past trends and the prediction of the occurrence of extreme climate events on rainfall and temperature using different approaches. Several studies have therefore achieved this by the use of RCMs. This model has been frequently used for climate change impact studies (Zhang et al. 2008) and future extreme climate projections analysis (Tomassini and Jacob 2009).

In West Africa, M'Po et al. (2017) assessed climate change impact on rainfall extremes over the Ouémé River Basin in Benin using RCM. The results showed a decrease in extremely heavy precipitation and annual total wet-day precipitation in most stations for the future 2015-2050. The Vea catchment in Ghana is seen as one of the vulnerable areas to climate change and is faced with issues of climate shocks such as flood and drought. This has devastating effects on various sectors of the economy particularly water resources and agriculture. However, information regarding climate change and climate extremes which are vital to improve societal awareness and preparedness is limited in the Vea catchment. To this end, understanding trends and variations of historical and future climatic variables is pertinent for the future development and sustainable water resources management in the catchment (Ogountundé et al. 2006). This chapter assesses the impact of climate change on rainfall and temperature extreme indices in the Vea catchment in the Upper East Region of Ghana. This is based on the Representative Concentration Pathways (RCP 4.5) scenario, which would recommend adaptation strategies required at the community level to reduce the vulnerability of the people to the risk of climate change and extreme events in the future. 


\section{Description of the Study Area and Methodology}

This section describes the area where the study was conducted, the data used, and the methodology applied to achieve the aim of the study. The Vea catchment, one of the sub-catchments within the White Volta basin (WVB), is located between latitudes $10^{\circ} 30^{\prime} \mathrm{N}-11^{\circ} 08^{\prime} \mathrm{N}$ and longitudes $1^{\circ} 15^{\prime} \mathrm{W}-0^{\circ} 50^{\prime} \mathrm{E}$ (Fig. 1). It has an area of about $305 \mathrm{~km}^{2}$ and covers mainly the Bongo and Bolgatanga districts in the Upper East Region of Ghana, with a small portion over the south-central part of Burkina Faso. The climate of the catchment is controlled by the movement of the Inter-tropical Discontinuity (ITD) over the land that dominates the climate of the entire West African region (Obuobie 2008). Located in a semiarid agroclimatic zone, the catchment covers three agroecological zones: the Savanna and Guinea Savanna zones in Ghana, and north Sudanian Savanna zone in Burkina Faso (Forkuor 2014). It is characterized by a unimodal rainfall regime from April/May to October with a mean annual rainfall of $957 \mathrm{~mm}$ which normally peaks in August (Larbi et al. 2018). The temperature is uniformly high with a mean value of $28.5^{\circ} \mathrm{C}$ while potential evapotranspiration in the catchment exceed monthly rainfall for most part of the year, except the three wettest months of July, August, and September (Limantol et al. 2016). It is characterized by fairly low relief with elevation ranging between $89 \mathrm{~m}$ and $317 \mathrm{~m}$ (Fig. 1) and mainly dominated by cropland followed by grassland interspersed with shrubs and trees and woodland (closed/open).

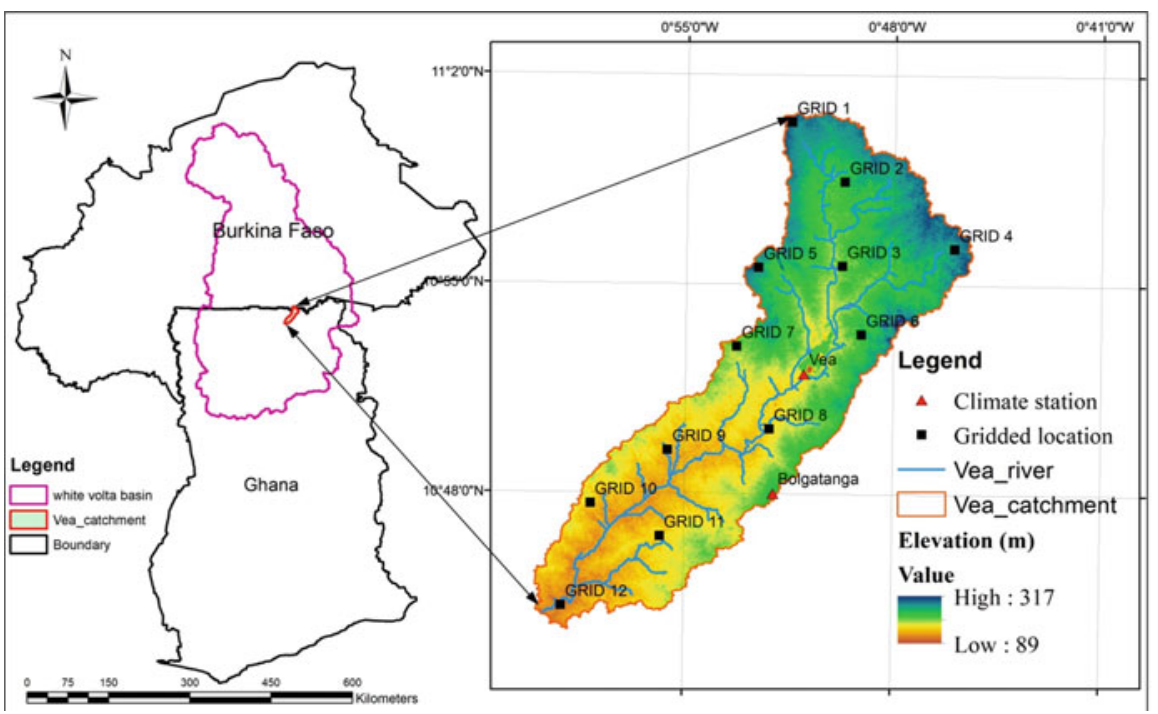

Fig. 1 Map of the Vea catchment showing the station and gridded precipitation locations within a $12 \mathrm{~km}$ grid 


\section{Observation and Climate Change Scenario Datasets}

Observed daily rainfall, maximum and minimum temperature within the Vea catchment from 1986 to 2016 for two climate stations (Vea and Bolgatanga) were obtained from the West African Science Service Centre on Climate Change and Adapted Land Use (WASCAL) research center and Ghana Meteorological Agency. Additional 12 (Fig. 1) gridded daily precipitation data at $0.05^{\circ}$ spatial resolution from Climate Hazards Group InfraRed Precipitation with Station data (CHIRPS) were also downloaded from http://chg.geog.ucsb.edu/data/chirps (Funk et al. 2015). CHIRPS incorporate satellite imagery with in-situ station data to create gridded rainfall time series. The performance of the CHIRPS data in reproducing the climatology of the Vea catchment has been evaluated in previous research (Larbi et al. 2018). According to Larbi et al. (2018), the CHIRPS data is able to reproduce well both the seasonal and annual rainfall pattern of the Vea catchment, and the validation resulted in a very high correlation coefficient $(\mathrm{r}=0.99)$ and a Nash-Sutcliffe efficiency of 0.9.

Four RCMs datasets (Table 1) within the CORDEX-Africa experiment and Weather Research and Forecasting (WRF) models were obtained from both CORDEX-Africa website and WASCAL geoportal (Heinzeller et al. 2016), respectively. The CORDEX-Africa RCMs have been selected based on its ability to simulate the basic climatological features in West Africa (Kim et al. 2013). The WRF simulations were produced by the Karlsruhe Institute of Technology, Institute of Meteorology and Climate Research, Atmospheric Environmental Research (KIT/IMK-IFU), Germany, and the West African Science Service Centre on Climate Change and Adapted Land Use (WASCAL) regional climate simulations. The WRF (WRF-H and WRF-G) simulations were downscaled from two GCMs namely: the General Fluid Dynamics Laboratory Earth System Model (GFDL-ESM 2 M) and the Hadley Global Environment Model (HadGEM2-ES) using the Weather Research and Forecasting Model (WRFv3.5.1). A detailed technical description and parameterization of the WRF models have been reported by Heinzeller et al. (2017). The CORDEX-Africa RCMs (REMO2009 and KNMI-RACMO22T) and the WRF models were selected due to its remarkable skills in reproducing the climatology of the Vea catchment for the period 1981-2005 (Larbi et al. 2020). The WRF models skills have also demonstrated to do well in terms of rainfall distribution in a study conducted within West

Table 1 Description of the CORDEX-Africa and WRF models whose ensemble mean was used

\begin{tabular}{l|l|l|l}
\hline GCMs & RCMs & Institution & Resolution \\
\hline ICHEC-EC-EARTH & REMO2009 & $\begin{array}{l}\text { Max Planck Institute - Computational } \\
\text { methods in systems and control theory } \\
\text { (MPI-CSC), Germany }\end{array}$ & $50 \mathrm{~km}$ \\
\hline ICHEC-EC-EARTH & $\begin{array}{l}\text { KNMI- } \\
\text { RACMO22T }\end{array}$ & $\begin{array}{l}\text { Koninklijk Nederlands Meteorologisch } \\
\text { Instituut (KNMI) }\end{array}$ & $50 \mathrm{~km}$ \\
\hline HadGEM2-ES & WRF-H & WASCAL / KIT/IMK-IFU & $12 \mathrm{~km}$ \\
\hline GFDL-ESM2M & WRF-G & WASCAL / KIT IMK-IFU & $12 \mathrm{~km}$
\end{tabular}


Africa by Bessah et al. (2018). Details on the RCMs evaluation and bias-correction can be found in Larbi et al. (2020). The ensemble mean of the bias-corrected RCMs output used consist of daily rainfall and temperature for the future (2020-2049) under Representative Concentration Pathway (RCP4.5) climate change scenario.

\section{Climate Extreme Indices Analysis}

Several climate extreme indices have been developed by the Expert Team on Climate Change Detection Monitoring Indices (ETCCDMI) for understanding climate extremes and are widely used in several regions (Mouhamed et al. 2013; Soro et al. 2016; M'Po et al. 2017). Six of the indices were adopted. The selected rainfall and temperature extreme indices (Table 2) were computed for each climate location for both the historical (1986-2016) and future (2020-2049) period on the interface of R software using RClimdex. The historical extreme indices was computed using climate observation data while the future climate extreme indices were computed based on the ensemble mean of the RCMs data for the RCP 4.5 climate change scenario. The computed rainfall and temperature extremes indices at the annual scale were analyzed at spatial and temporal scale using the inverse distance weighting (IDW) technique (Feng-Wen and Chen-Wuing 2012). Trends in the climate extreme indices time series were computed based on the parametric linear regression approach (M'Po et al. 2017).

\section{Presentation of Results and Discussion}

\section{Annual Rainfall and Temperature Projections and Trends}

The results for the projections of mean annual rainfall and temperature in the Vea catchment by the ensemble mean of the RCMs under the RCP4.5 scenario is shown in Fig. 2 and Table 3. The ensemble mean of the RCMs shows an increase in mean annual rainfall and temperature by $22.6 \mathrm{~mm}(2.4 \%)$ and $1.3{ }^{\circ} \mathrm{C}$, respectively, for the

Table 2 Climate extreme indices

\begin{tabular}{l|l|l|l}
\hline Indices & Descriptive name & Definition & Units \\
\hline PRCPTOT & $\begin{array}{l}\text { Annual total wet-day } \\
\text { precipitation }\end{array}$ & Annual total precipitation from days $\geq 1 \mathrm{~mm}$ & $\mathrm{~mm}$ \\
\hline R99p & Extremely wet days & $\begin{array}{l}\text { Annual total precipitation on the days when } \\
\text { daily PRCP }>99 \text { th percentile }\end{array}$ & $\mathrm{mm}$ \\
\hline CWD & Consecutive wet days & $\begin{array}{l}\text { Maximum number of consecutive days with } \\
\text { PRCP } \geq 1 \mathrm{~mm}\end{array}$ & days \\
\hline CDD & Consecutive dry days & $\begin{array}{l}\text { Maximum number of consecutive days with } \\
\text { PRCP }<1 \mathrm{~mm}\end{array}$ & days \\
\hline TXx & Warmest day & $\begin{array}{l}\text { Annual maximum value of the daily max } \\
\text { temperature }\end{array}$ & ${ }^{\circ} \mathrm{C}$ \\
\hline TNx & Warmest night & $\begin{array}{l}\text { Annual maximum value of daily min } \\
\text { temperature }\end{array}$ & ${ }^{\circ} \mathrm{C}$ \\
\hline
\end{tabular}



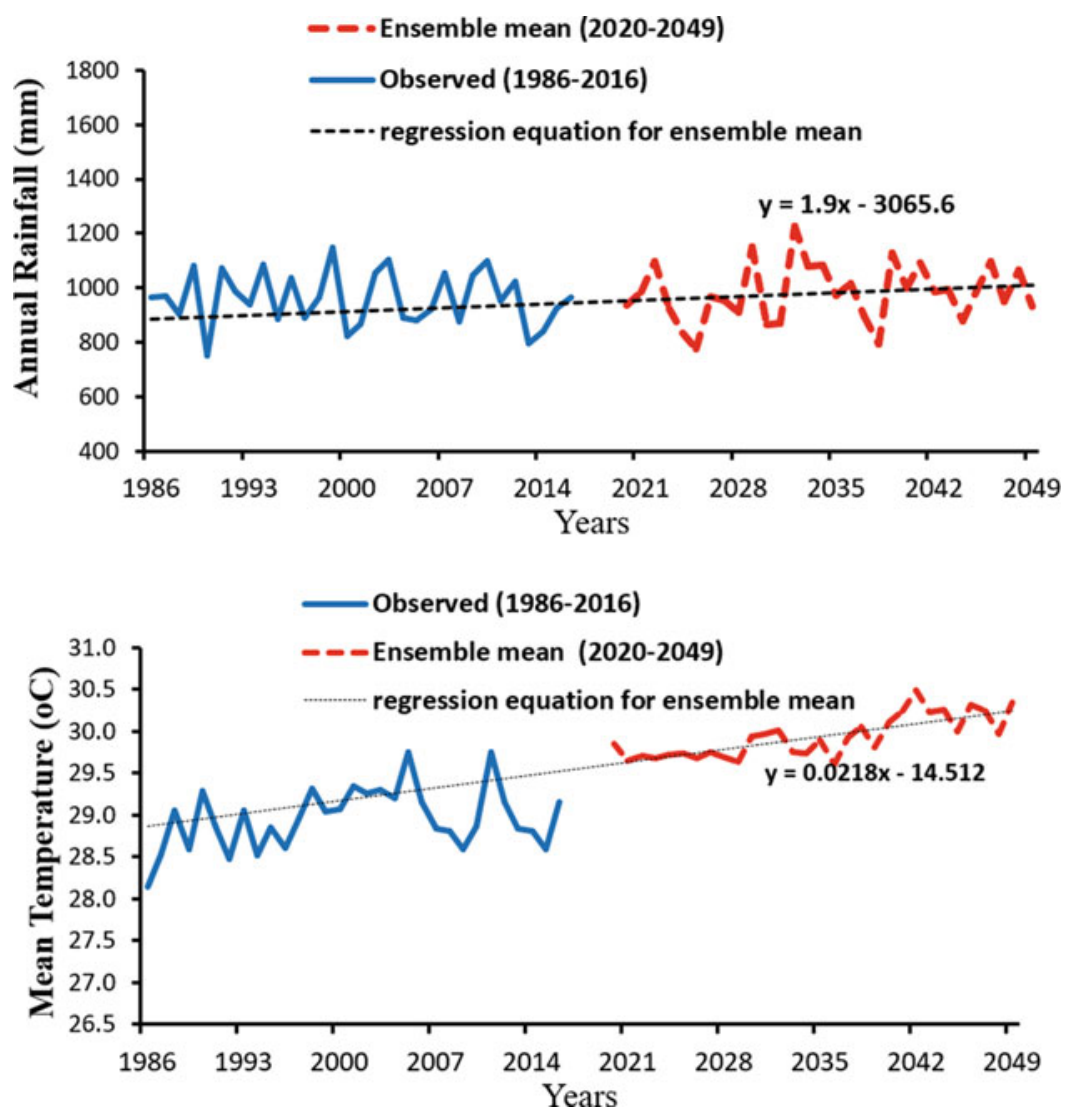

Fig. 2 Mean annual rainfall and temperature projection for the Vea catchment in the future (2020 2049) under RCP 4.5 scenario relative to the $1986-2016$ period

period 2020-2049 relative to the baseline (1986-2016) period. An increasing trend in the future annual rainfall and temperature was found to be at the rate of $1.9 \mathrm{~mm} /$ year and $0.02{ }^{\circ} \mathrm{C} /$ year.

\section{Trends and Projected Changes in Extreme Rainfall Indices}

The results for the extreme rainfall indices (PRCPTOT, CWD, CDD, and R99p) projected by the ensemble mean of the RCMs under RCP4.5 scenario relative to the baseline (1986-2016) period are shown in Table 4 and Fig. 3. The annual total precipitation (PRCPTOT) is projected to increase from $951.9 \mathrm{~mm}$ to $952.1 \mathrm{~mm}$ (Table 4) at an annual rate of $2.2 \mathrm{~mm} /$ year (Fig. 3a). Extremely wet days (R99p) is projected to increase by $29.1 \mathrm{~mm}$; however, a decreasing trend at a rate of $0.77 \mathrm{~mm} /$ year is projected in the future 2020-2049 (Fig. 3d). Unlike consecutive dry days 
Table 3 Mean annual rainfall and temperature projections for the Vea catchment relative to the baseline period

\begin{tabular}{l|l|l|l}
\hline Variables & Baseline (1986-2016) & RCP4.5 (2020-2049) & Change \\
\hline Tmax $\left({ }^{\circ} \mathrm{C}\right)$ & 34.6 & 35.9 & 1.3 \\
\hline Tmin $\left({ }^{\circ} \mathrm{C}\right)$ & 22.6 & 24.0 & 1.4 \\
\hline Tmean $\left({ }^{\circ} \mathrm{C}\right)$ & 28.6 & 29.9 & 1.3 \\
\hline Rainfall $(\mathrm{mm})$ & 958.5 & 981.1 & $2.4 \%$ \\
\hline
\end{tabular}

Table 4 Projected changes in mean annual climate extreme indices at the Vea catchment

\begin{tabular}{l|l|l|l}
\hline Climate extreme indices & Baseline (1986-2016) & RCP4.5 (2020-2049) & Change \\
\hline PRCPTOT $(\mathrm{mm})$ & 951.9 & 952.1 & 0.2 \\
\hline R99p $(\mathrm{mm})$ & 46.6 & 75.7 & 29 \\
\hline CWD (days) & 5 & 4 & -1 \\
\hline CDD (days) & 105 & 131 & 26 \\
\hline TXx $\left({ }^{\circ} \mathrm{C}\right)$ & 41.5 & 42.3 & 0.8 \\
\hline TNx $\left({ }^{\circ} \mathrm{C}\right)$ & 28.9 & 29.2 & 0.3 \\
\hline
\end{tabular}

(CDD) which is projected to increase from 105 to 131 days, consecutive wet days (CWD) is projected to decrease by 1 day in the future 2020-2049 (Table 4). The spatial distribution of the extreme rainfall indices (Fig. 4) indicates a projected increase in CDD in most part of the catchment, with the exception of the center parts of the catchment that shows a decrease of 5 days (Fig. 4c). The PRCPTOT is projected to decrease in most parts of the catchment except the extreme north and south which shows an increase of $28.7 \mathrm{~mm}$ (Fig. 4f). R99p is projected to increase in all parts of the catchment especially in the northern and southern parts and will range from 27.7 to $35.7 \mathrm{~mm}$ (Fig. 4L). Unlike R99p, CWD is projected to decrease in the entire catchment in the range of -3.4 to -0.4 days (Fig. $4 \mathrm{I}$ ).

\section{Temperature Extreme Indices Projections and Trends}

The time series of the projected extreme temperature indices (TXx and TNx) and its spatial distribution are shown in Figs. 5 and 6, respectively. As shown in Table 4, the warmest day (TXx) is projected to increase by $0.8{ }^{\circ} \mathrm{C}$ from $41.5^{\circ} \mathrm{C}$ to $42.3{ }^{\circ} \mathrm{C}$. The warmest night (TNx) is also projected to increase from $28.9^{\circ} \mathrm{C}$ to $29.2{ }^{\circ} \mathrm{C}$. The future trend analysis of the extreme temperature indices shows an increasing trend in both TXx and TNx at a rate of 0.04 and $0.01{ }^{\circ} \mathrm{C} / \mathrm{year}$, respectively. At spatial scale, TXx is projected to increase in the entire catchment for the period 2020-2049, with a higher increase in the southern part of the catchment in the range of 0.79 to $1.29^{\circ} \mathrm{C}$. The TNx is also projected to increase in the range of $0.0^{\circ} \mathrm{C}$ to $0.48{ }^{\circ} \mathrm{C}$ in the greater part of the Vea catchment. 


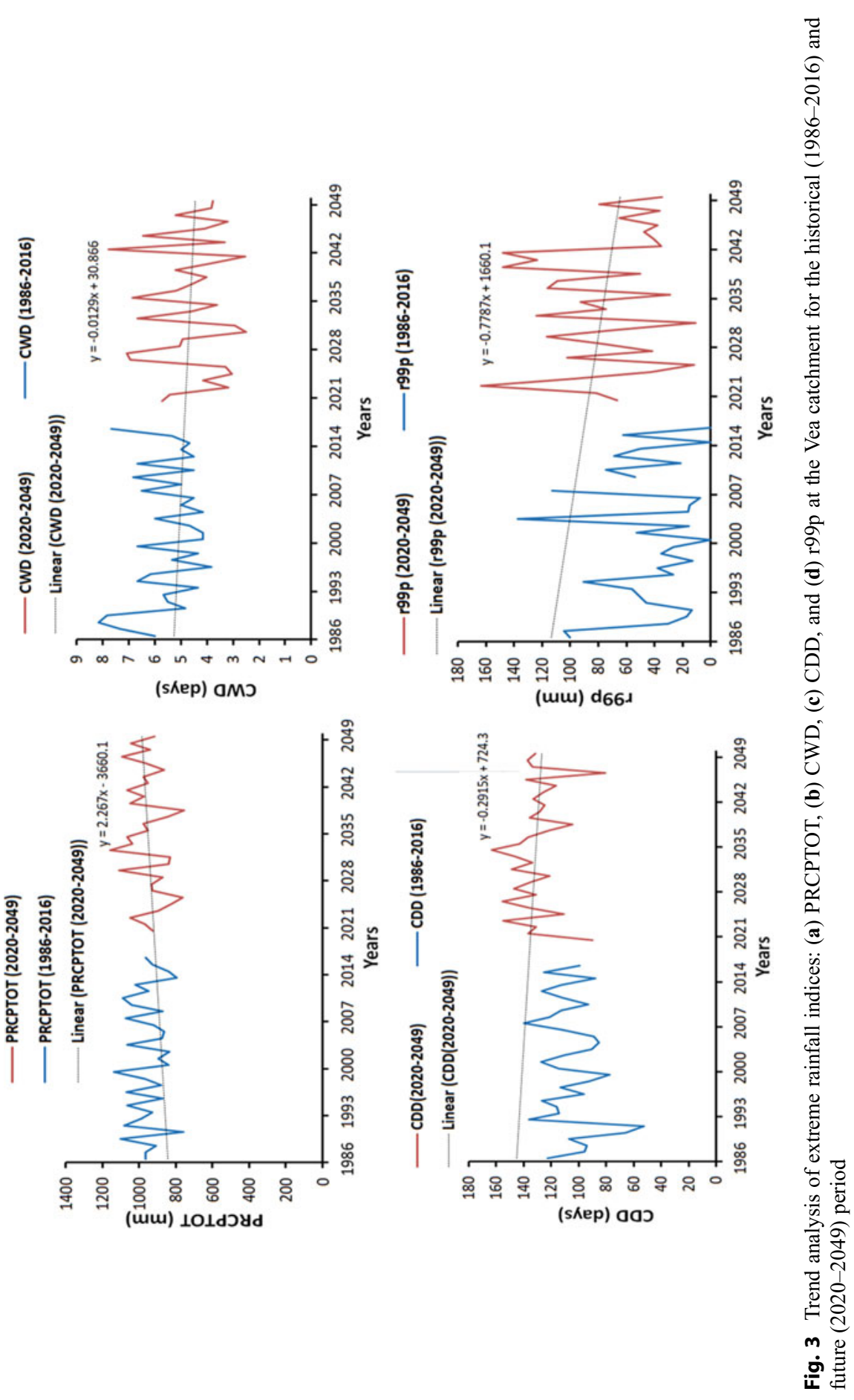



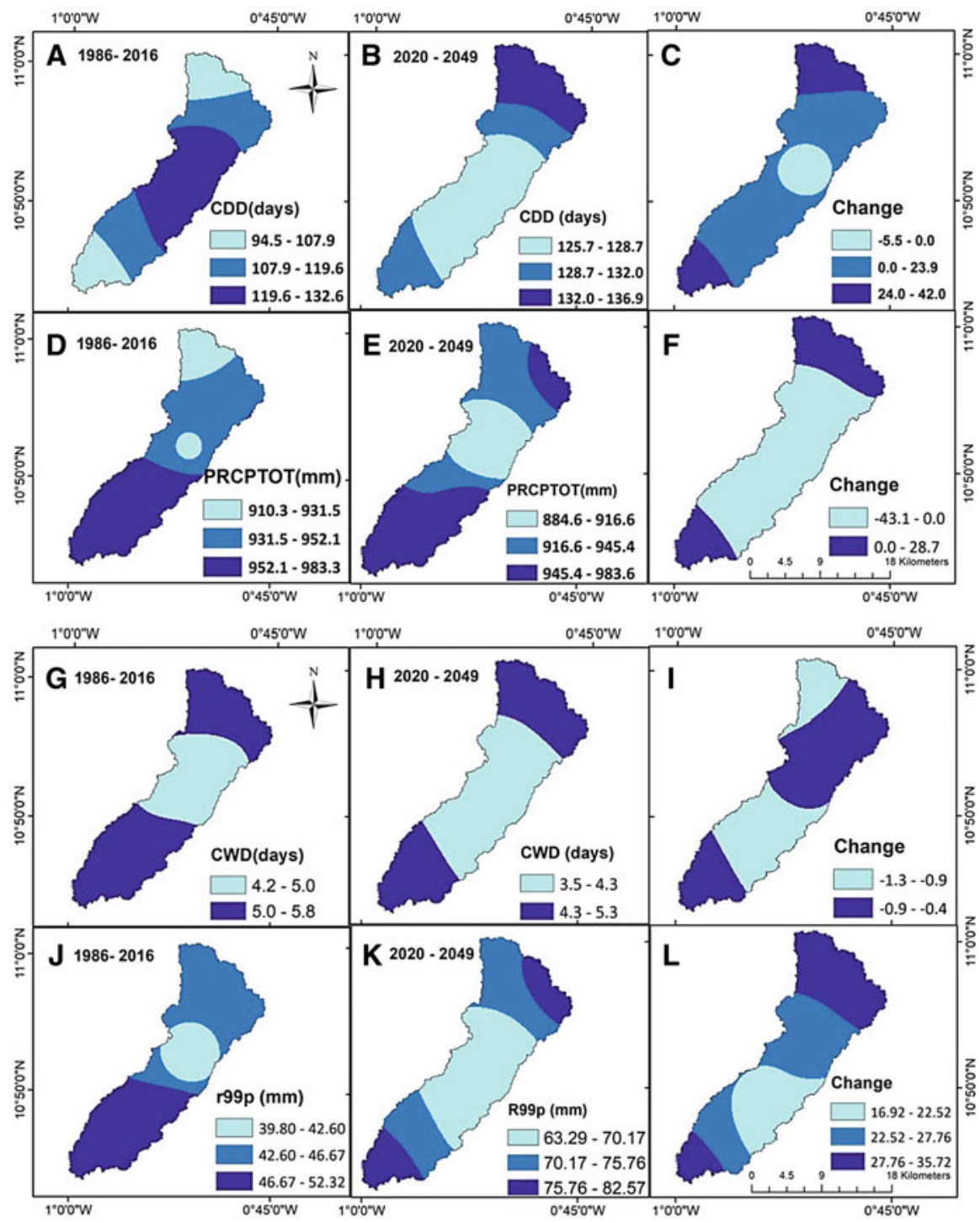

Fig. 4 Spatial distribution of the projected changes in the extreme rainfall indices: (a) CDD, (b) PRCPTOT, (c) CWD, and (d) r99p in the Vea catchment

\section{Climate Change and Climate Extreme Impacts at the Study Region}

The agroclimatic zone of the Vea catchment is characterized as semiarid region in West Africa and can influence growth when managed efficiently. With the expected increase in precipitation and temperature, there is a likelihood of potential risk to 
Fig. 5 Trend analysis of extreme temperature indices for TXx and TNx in the Vea catchment for the historical and future period
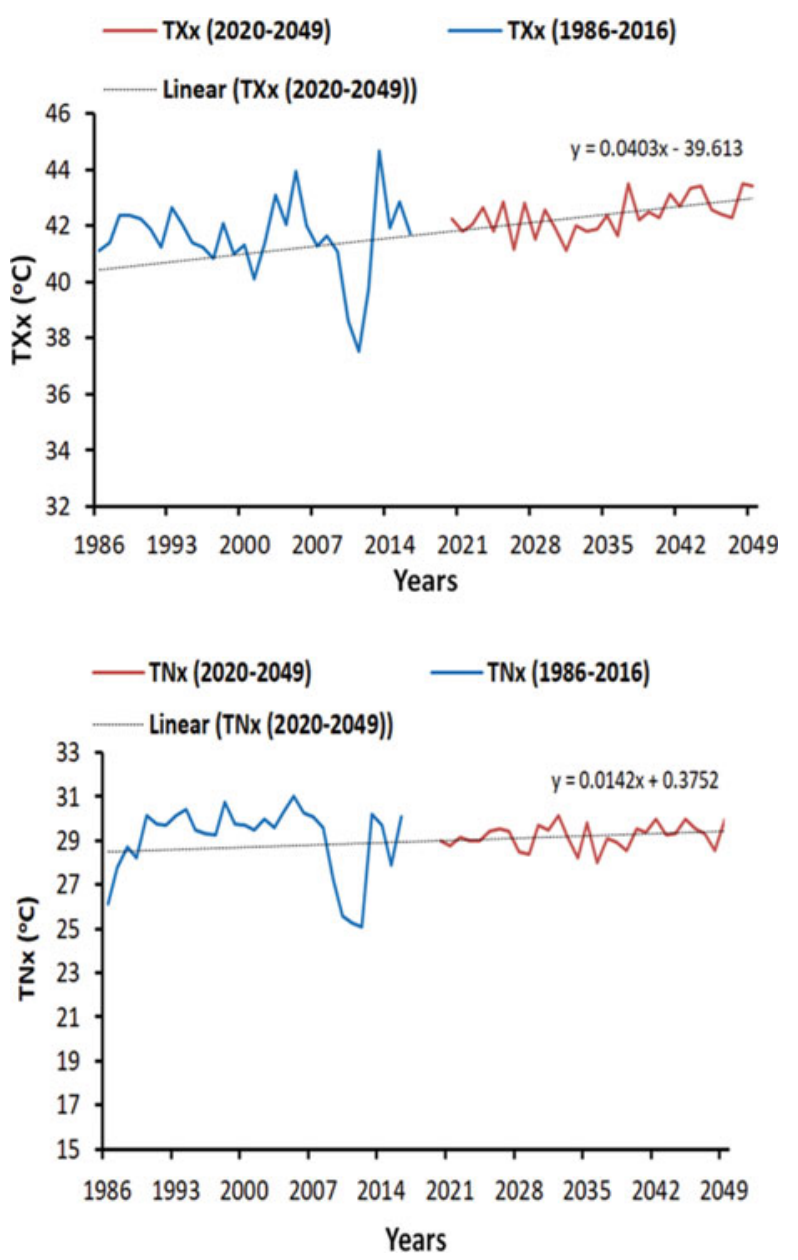

natural disasters and destruction of infrastructure which would have environmental, economic, and societal implications (Gobiet et al. 2014). The climate analysis performed on the daily rainfall and temperature series for the historical and future period provides evidence that the Vea catchment would be affected by climate change and warm extremes based on the indices analyzed with warming more pronounced during the day than the night. Although in Ghana climate change projections vary considerably among different models, there is a consensus on the evidence of increasing temperature across the country. The mean annual temperature at the Vea catchment is projected to increase by $1.3{ }^{\circ} \mathrm{C}$ for the period $2020-2049$. This finding is in line with observations reported by other climate change studies (e. g., McSweeney et al. 2010a; De Pinto et al. 2012). Additionally, a study by De Pinto et al. (2012) reported a projected increase in the mean annual temperature of Ghana 


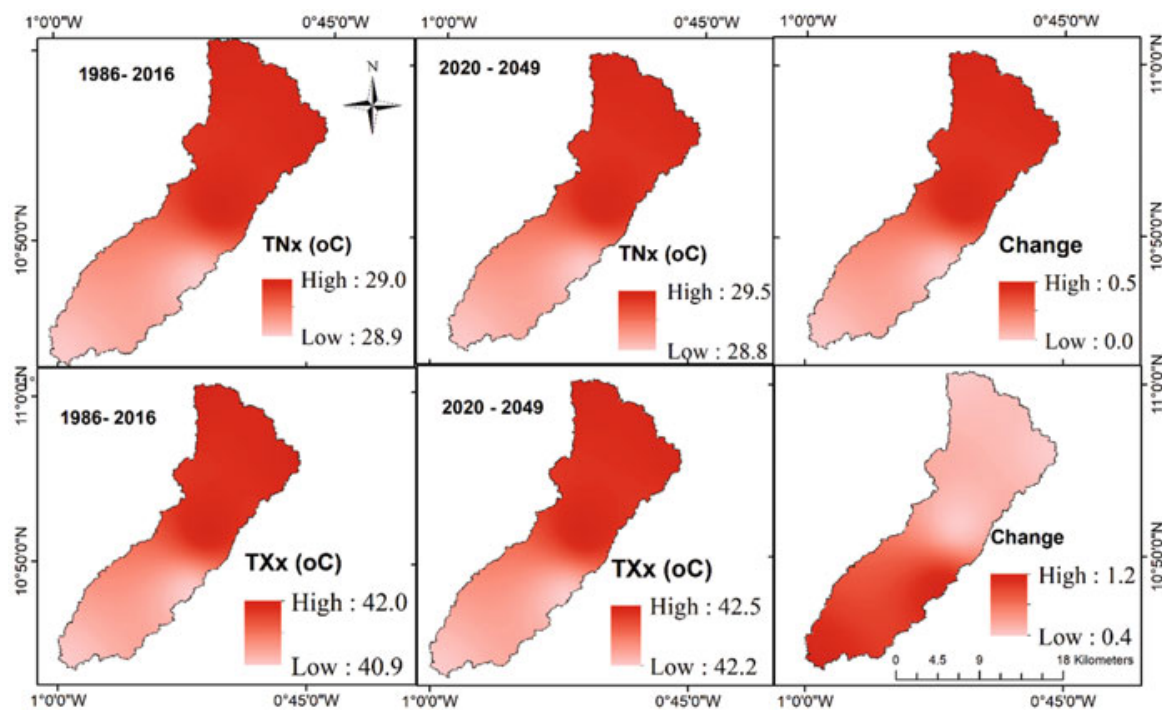

Fig. 6 Spatial distribution of the projected changes in the TNx and TXx temperature indices relative to the baseline (1986-2016) period

in the range of $1.0-3.0^{\circ} \mathrm{C}$ by 2060 and by $1.5-5.2^{\circ} \mathrm{C}$ by 2090 , with more rapid increases expected in the northern sector of the country. Similar increase in temperature of $0.6^{\circ} \mathrm{C}, 2.0^{\circ} \mathrm{C}$, and $3.9^{\circ} \mathrm{C}$ by the year 2020,2050 , and 2080 , respectively, in Ghana has also be projected by the Ministry of Environment Science, Technology and Innovation of Ghana [MESTI] (2013). These projections in temperature are noticed to be across all regions in the country with a rapid increase in the northern sector (World Bank 2010). However, rainfall projections in Ghana are characterized with greater uncertainties with some models predicting an increase while others a decrease (McSweeney et al. 2010b).

In terms of climate extremes, the study region has witnessed periodic extreme climate shocks and disasters such as high temperature, highly variable and erratic rainfall, and long spells of droughts (Kanlisi and Arkum 2013). According to EPA (2007), such extreme weather events are expected to intensify in the region by 2080. The ensemble mean of the four climate models projected a nonsignificant increase in the mean annual rainfall; however, there exist spatial variations in the annual total rainfall (PRCPTOT), CWD, and CDD with some part of the Vea catchment indicating an increase while other parts indicate a decrease in the future period. These projections in climate change and extremes would have serious socioeconomic impacts on rural farmers in Ghana whose livelihoods depend largely on rainfall (Abeygunawardena et al. 2003; Fosu-Mensah et al. 2012). The changes in climate would affect agriculture and other sectors such as water resources, especially in the Upper East Region of Ghana where the Vea catchment is located (Gyasi et al. 2006). The projected warming trend at the Vea catchment lead to a higher evaporative demand from water bodies and irrigated crops in the future. Limantol et al. (2016) 
indicated that temperature and evapotranspiration have been on the increase in the Vea catchment. And according to Ofori-Sarpong (2001), the increase in evapotranspiration could lead to soil moisture deficit and poor crop yield, particularly when there is no corresponding significant increase in rainfall. Also, evapotranspiration propelled by temperature will majorly affect agriculture through droughts and soil moisture deficits (Limantol et al. 2016).

\section{Existing and Recommended Adaptation Strategies to Address Poverty and Ensure Sustainable Livelihoods in the Catchment}

In sub-Saharan Africa, adapting to the impact of climate change on agriculture and other sectors of the economy has become a major concern to various stakeholders with special emphasis on improving adaptive capacity (Apata 2011). The projected climate change and extremes at the Vea catchment underscore the need to put in place appropriate adaptation measures to foster resilience to climate change in order to enhance water security and livelihood of the people within the area. In the Vea catchment, Limantol et al. (2016) examined farmers' perceptions and adaptation practices to climate change and variability, and noticed that farmers are aware of climate change and are adopting strategies to cope with the effects. At the catchment, some farmers use rain-fed practices to adjust to climate variability by varying crop types via rotation without fertilizer, while others employ irrigation practices to offset climate variability with a greater use of fertilizer application. According to Limantol et al. (2016), farmers identified irrigation development (access to water), followed by access to credit and health services as the most urgent needs for adaption to climatic change in the Vea catchment. Similarly, Kumasi et al. (2017) also reported that, the farmers in the Upper East Region of Ghana mostly practice crop selection, changes to planting dates and density, communal pooling (e.g., labor or income sharing across households), and traditional irrigation techniques as adaptation strategies to climate change. Additionally, Lawson et al. (2019) investigated the intersectional perceptions and adaptation strategies of women farmer in dealing with climate change in semiarid regions of Ghana. It was revealed that women farmers perceived the occurrence of climate change in the community and have incorporated some adaptation measures to counter its impacts. These adaptation strategies include changing planting dates, mixed farming, intercropping, planting early maturing varieties, composting, and seeking off-farm activities.

In Ghana, national climate change adaptation strategy has been developed and various adaptation programs and strategies have been outlined to combat climate change. Some of these strategies include: (i) increasing resilience to climate change impacts: identifying and enhancing early warning systems, and (ii) alternative livelihoods: minimizing impacts of climate change for the poor and vulnerable needs to be implemented at the study catchment to help reduce the vulnerability of the people to future climate change and extremes. Other adaptation strategies recommended for the Vea catchment include: 
1. Implementation of water use efficiency system as part of effective management of water resources at the catchment. Due to the projected increased in temperature and the variability in rainfall, water use efficiency system such as drip irrigation needs to be promoted to ensure not only all year-round farming but also reduce demands from the three main water sectors: domestic supply, agriculture, and industry.

2. Enhance local capacity to adapt to climate change through improved land use management and agricultural diversification.

3. Awareness creation on the need to protect and effectively manage the Vea dam and streams within the Vea catchment through the creation of vegetation buffers to protect the water resources.

4. Developing early warning systems and farmers access to climate information so as to adequately inform policy makers and enhance farmers' resilience to extreme events as a result of climate change.

\section{Conclusions}

The changes in future climate and extremes indices in the Vea catchment was computed from the Expert Team on Climate Change Detection Monitoring Indices based on the observed climate and multi-model mean of four bias-corrected RCMs. The climate simulation under RCP4.5 scenario for the catchment show a warmer climate with $1.3{ }^{\circ} \mathrm{C}$ temperature increase in 2020-2049. The trend analysis of the rainfall and temperature extremes indices indicated a continuous extreme temperature rise as well as an increase in intensity of extreme rainfall events in 2020-2049 at the catchment. The projected increase in extreme temperature (TXx and TNx), intensity (R99p), and frequency (CDD) of extreme rainfall indicate the catchment vulnerability to the risk of climate disasters, hence the need for decision-makers to adapt and mitigate climate change over the area. The study also provided evidence that the daily maximum temperature (warmest day) would increase at a faster rate compared to the daily minimum temperature (warmest night), indicating more warming in the day compared to the night. Encouraging adaptation policies such as rainwater harvesting, availability climate information, flood control measures, and the development of early warning systems are necessary at the Vea catchment to mitigate the effects of future extreme climate events.

\section{References}

Abeygunawardena P, Vyas Y, Knill P, Foy T, Harrold M, Steele P, Sperling F (2003) Part 1. Poverty and climate change: reducing the vulnerability of the poor through adaptation. World Bank, Washington, DC. Accessed 28 Aug 2019. http://agris.fao.org/agris-search/search.do? recordID $=$ US2012416506

Adeyeri OE, Lawin AE, Laux P, Ishola KA, Ige SO (2019) Analysis of climate extreme indices over the Komadugu-Yobe basin, Lake Chad region: past and future occurrences. Clim Extrem 29:21-39 
Alexander LV, Zhang X, Peterson TC, Caesar J, Gleason B, Klein Tank AMG, Vazquez-Aguirre JL (2006) Global observed changes in daily climate extremes of temperature and precipitation. J Geophys Res Atmos 111:D05109. https://doi.org/10.1029/2005JD006290

Amuzu J, Kabo-Bah AT, Jallow BP, Yaffa S (2018) Households' livelihood vulnerability to climate change and climate variability. A case study of the coastal zone, the Gambia. J Environ Earth Sci 8:35-46. https://doi.org/10.13140/RG.2.2.36057.42081

Apata TG (2011) Factors influencing the perception and choice of adaptation measures to climate change among farmers in Nigeria. Evidence from farm households in Southwest Nigeria. Environ Econ 2(4):74-83

Awotwi A, Kumi M, Jansson PE, Yeboah F, Nti IK (2015) Predicting hydrological response to climate change in the White Volta Catchment, West Africa. J Earth Sci Clim Change 6:249. https://doi.org/10.4172/2157-7617.1000249

Bessah E, Raji AO, Taiwo OJ, Agodzo SK, Ololade OO (2018) Variable resolution modeling of near future mean temperature changes in the dry sub-humid region of Ghana. Modeling Earth Systems and Environment 4(3):919-933. https://doi.org/10.1007/s40808-018-0479-0

Bohle HG, Downing TE, Watts MJ (2018) Climate change and social vulnerability toward a sociology and geography of food insecurity. Glob Environ Change 4:37-48. https://doi.org/ 10.1016/0959-3780(94)90020-5

Chen H, Chong-Yu X, Guo S (2012) Comparison and evaluation of multiple GCMs, statistical downscaling and hydrological models in the study of climate change impacts on runoff. $\mathrm{J}$ Hydrol 434-435:36-45

De Pinto A, Demirag U, Haruna A, Koo J, Asamoah M (2012) Climate change, agriculture, and food-crop production in Ghana. International Food Policy 213 Research Institute Policy note \#3: Ghana Strategy Support Program, International Food Policy Research Institute. Available: http://www.ifpri.org/sites/default/files/publications/gssppn3.pdf. Accessed 20 Sept 2014

Environmental Protection Agency (2007) Climate change and the Ghanaian economy. In: Policy advice series, vol 1. Environmental Protection Agency of Ghana, Accra

FAO (2013) The State of Food Insecurity in the World 2013. The multiple dimensions of food security. FAO, Rome. ISBN 978-92-5-107916-4

Feng-Wen C, Chen-Wuing L (2012) Estimation of the spatial rainfall distribution using inverse distance weighting (IDW) in the middle of Taiwan. Paddy Water Environ 10:209-222. https:// doi.org/10.1007/s10333-012-0319-1

Forkuor G (2014) Agricultural land use mapping in West Africa using multi-sensor satellite imagery. $\mathrm{PhD}$ dissertation, Julius-Maximilians-Universität Würzburg

Fosu-Mensah BY, Vlek PLG, MacCarthy DS (2012) Farmers' perception and adaptation to climate change: a case study of Sekyedumase district in Ghana. Environ Dev Sustain 14:495-505

Funk C, Peterson P, Landsfeld M, Pedreros D, Verdin J, Shukla S, ... Michaelsen J (2015) The climate hazards infrared precipitation with stations - a new environmental record for monitoring extremes. Sci Data 2:150066. https://doi.org/10.1038/sdata.2015.66

Gobiet A, Kotlarski S, Beniston M, Heinrich G, Rajczak J, Stoffel M (2014) 21st century climate change in the European Alps - a review. Sci Total Environ 493:1138-1151

Gyasi EA, Karikari O, Kranjac-Berisavljevic G, Vordzogbe V (2006) Climate change vulnerability and adaptation assessment relative to land management in Ghana. Reports of the Members of the Study Team, Accra

Heinzeller D, Olusegun C, Kunstmann H (2016) Projected future (2070-2099): High Resolution (12km) WRF-MPI Daily Near-Surface Relative Humidity over West Africa, (WASCAL Project). https://wascal-dataportal.org/geonetwork/?uuid=0cafe3f0-adf5-43d7-9483-6fbd2b05d86d

Heinzeller D, Dieng D, Smiatek G, Olusegun C, Klein C, Hamann I, Salack S, Kunstmann H (2017) The WASCAL high-resolution regional climate simulation ensemble for West Africa: concept, dissemination, assessment. Earth Syst Sci Data Discuss. https://doi.org/10.5194/essd-2017-93

Kanlisi KS, Arkum TA (2013) Builsa community vulnerability and capacity assessment in the Upper East Region of Ghana. Eur Sci J Ed 9(29):144-164. e-ISSN: 1857-7431

Kim J, Waliser DE, Mattmann CA, Goodale CE, Hart AF, Zimdars PA, Daniel J (2013) Evaluation of the CORDEX-Africa multi-RCM hindcast: systematic model errors. Clim Dyn 42(5-6):1189-1202. https://doi.org/10.1007/s00382-013-1751-7 
Kumasi TC, Antwi-Agyei P, Obiri-Danso K (2017) Small-holder farmers' climate change adaptation practices in the Upper East Region of Ghana. Environ Dev Sustain. https://doi.org/10.1007/ s10668-017-0062-2

Larbi I, Hountondji FCC, Annor T, Agyare WA, Gathenya JM, Amuzu J (2018) Spatio-temporal trend analysis of rainfall and temperature extremes in the Vea catchment. Climate 6(87):1-17. https://doi.org/10.3390/cli6040087

Larbi I, Hountondji FCC, Mama D, Nyamekye C, Adeyeri OE, Koubodana DH, Odoom PRE, Asare YM (2020) Local Climate change projections and impact on the surface hydrology in the Vea catchment, West Africa. Hydrology Research, In press. https://doi.org/10.2268/nh.2020.022

Lawson E T, Alare RS, Salifu ARZ, Thompson-Hall M (2019). Dealing with climate change in semi-arid Ghana: understanding intersectional perceptions and adaptation strategies of women farmers. GeoJournal. https://doi.org/10.1007/s10708-019-09974-4

Limantol AM, Keith BE, Azabre BA, Lennartz B (2016) Farmers' perception and adaptation practice to climate variability and change: a case study of the Vea catchment in Ghana. Springerplus 5:830. https://doi.org/10.1186/s40064-016-2433-9

M'Po YN, Lawin EA, Yao BK, Oyerinde GT, Attogouinon A, Afouda AA (2017) Decreasing past and mid-century rainfall indices over the Ouémé River Basin, Benin (West Africa). Climate 5:74. https://doi.org/10.3390/cli5030074

Maraun D, Wetterhall F, Ireson AM, Chandler RE, Kendon EJ, Widmann M, ... Thiele-Eich I (2010) Precipitation downscaling under climate change: recent developments to bridge the gap between dynamical models and the end user. Rev Geophys 48:RG3003. https://doi.org/10.1029/ 2009RG000314

McSweeney C, New M, Lizcano G (2010a) UNDP climate change country profiles: Ghana. Available: http://country-profiles.geog.ox.ac.uk. Accessed 24 Feb 2018

McSweeney C, New M, Lizcano G, Lu X (2010b) The UNDP climate change country profiles. Am Meteorol Soc 91:157-166

Ministry of Environment Science, Technology and Innovation (2013) Ghana national climate change policy. Ministry of Environment Science, Technology and Innovation, Accra

Minville M, Brissette F, Krau S, Leconte R (2009) Adaptation to climate change in the management of a Canadian water-resources system exploited for hydropower. Water Resour Manag 23:29652986

Mouhamed L, Traore SB, Alhassane A, Sarr B (2013) Evolution of some observed climate extremes in the West African Sahel. Weather Clim Extrem 1:19-25

New M, Hewitson B, Stephenson DB, Tsiga A, Kruger A, Manhique A, ... Lajoie R (2006) Evidence of trends in daily climate extremes over southern and West Africa. J Geophys Res 111: D14102. https://doi.org/10.1029/2005JD006289

Obuobie E (2008) Estimation of groundwater recharge in the context of future climate change in the White Volta River Basin. PhD dissertation, Rheinische Friedrich Wilhelms Universität, Bonn

Ofori-Sarpong E (2001) Impact of climate change on agriculture and farmers coping strategies in the Upper East Region of Ghana. West Afr J Appl Ecol 2:21-35

Ogountundé PG, Friesen J, van de Giesen N, Savenije HHG (2006) Hydroclimatology of the Volta River Basin in West Africa: trends and variability from 1901 to 2002. Phys Chem Earth 31:1180-1188

Panday PK, Thibeaultb J, Freyc KE (2015) Changing temperature and precipitation extremes in the Hindu Kush-Himalayan region: an analysis of CMIP3 and CMIP5 simulations and projections. Int J Climatol 35:3058-3077. https://doi.org/10.1002/joc.4192

Sarr B (2012) Present and future climate change in the semi-arid region of West Africa. A crucial input for practical adaptation in agriculture. Atmos Sci Lett 13:108-112. https://doi.org/10. $1002 /$ asl.368

Seager R, Vecchi GA (2010) Greenhouse warming and the 21st century hydroclimate of southwestern North America. Proc Natl Acad Sci 107(50):21277-21282

Soro GE, Noufé D, Goula Bi TA, Shorohou B (2016) Trend analysis for extreme rainfall at subdaily and daily timescales in Côte d'Ivoire. Climate 4:37 
Sylla MB, Diallo I, Pal JS (2013) West African monsoon in state-of-the-science regional climate models. In: Climate variability-regional and thematic patterns. IntechOpen. https://doi.org/10. $5772 / 55140$

Tomassini L, Jacob D (2009) Spatial analysis of trends in extreme precipitation events in highresolution climate model results and observations for Germany. J Geophys Res 114:D12113

Trenberth KE, Jones PD, Ambenje P, Bojariu R, ... Rusticucci M (2007) Observations: surface and atmospheric climate change, Chapter 3. In: Solomon S, Qin D, Manning M, Marquis M, Averyt KB, Tignor M, Miller HL, Chen Z (eds) Climate Change 2007: the physical science basis. Contribution of Working Group I to the Fourth Assessment Report of the Intergovernmental Panel on Climate Change. Cambridge University Press, Cambridge, UK/New York, pp 235-336

World Bank (2010) Economics of adaptation to climate change: synthesis report. The International Bank for Reconstruction and Development/World Bank, Washington, DC. Available: https:// openknowledge.worldbank.org/bitstream/handle/10986/12750/702670ESW0P10800EACC SynthesisReport.pdf? sequence=1. Accessed 26 Feb 2018

Xu CY (1999) From GCMs to river flow: a review of downscaling methods and hydrologic modeling approaches. Progr Phys Geogr 23(2), 229-249. 107, 21277-21282. https://doi.org/ 10.1073/pnas.0910856107

Zhang S, Lu XX, Higgitt DL, Chen CTA, Han J (2008) Recent changes of water discharge and sediment load in the Zhujiang (Pearl River) Basin, China. Glob Planet Chang 60:365-380

Open Access This chapter is licensed under the terms of the Creative Commons Attribution 4.0 International License (http://creativecommons.org/licenses/by/4.0/), which permits use, sharing, adaptation, distribution and reproduction in any medium or format, as long as you give appropriate credit to the original author(s) and the source, provide a link to the Creative Commons license and indicate if changes were made.

The images or other third party material in this chapter are included in the chapter's Creative Commons license, unless indicated otherwise in a credit line to the material. If material is not included in the chapter's Creative Commons license and your intended use is not permitted by statutory regulation or exceeds the permitted use, you will need to obtain permission directly from the copyright holder.

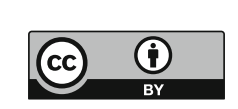

